\title{
KETAHANAN EKONOMI KELUARGA DI DEPOK PADA MASA PANDEMI COVID-19
}

\author{
Oleh: \\ Dhona Shahreza ${ }^{1}$ \\ Lindiawatie $^{2}$ \\ Program Studi Pendidikan Ekonomi \\ Fakultas Ilmu Pendidikan dan Pengetahuan Sosial \\ Universitas Indraprasta PGRI \\ Email: \\ denzanoena@gmail.com ${ }^{1}$ \\ lindiawatie@unindra.ac.id ${ }^{2}$
}

\begin{abstract}
ABSTRAK
Pembatasan Sosial Berskala Besar untuk mengendalikan penularan Covid-19 telah melumpuhkan perekonomian. Dampaknya adalah penurunan penghasilan yang berimbas pada kemampuan ekonomi keluarga bertahan selama pandemi Covid-19. Penelitian ini bertujuan untuk mengetahui ketahanan ekonomi keluarga di Depok pada masa pandemi Covid-19. Metode kualitatif deskriptif digunakan dengan subjek penelitian berjumlah 100 orang. Hasil penelitian menunjukkan ketahanan ekonomi keluarga di Depok dimasa pandemi Covid-19 mengalami penurunan khususnya dari sisi pendapatan dan kemampuan memenuhi kebutuhan keluarga. Namun dari aspek kepemilikan tempat tinggal, pembiayaan pendidikan anak, dan jaminan keuangan keluarga, ketahanan ekonomi keluarga di Depok dapat dinilai cukup baik. Penelitian ini merekomendasikan perlunya strategi pengelolaan keuangan keluarga yang cukup baik.
\end{abstract}

Kata kunci: Covid-19, keluarga, ketahanan ekonomi, pandemi

\begin{abstract}
Large-Scale Social Restrictions to control Covid-19 transmission have paralyzed the economy. The impact is a decrease in income which has an impact on the economic ability of families to survive during the Covid-19 pandemic. This study aims to determine the economic resilience of families in Depok during the Covid19 pandemic. The descriptive qualitative method was used with 100 subjects. The results showed that the economic resilience of families in Depok during the Covid19 pandemic had decreased, especially in terms of income and ability to meet family needs. However, from the aspect of housing ownership, financing children's education, and family financial security, the economic resilience of families in Depok can be considered quite good. This study recommends the need for a fairly good family financial management strategy.
\end{abstract}

Keywords: Covid-19, family, economic resilience, pandemic 


\section{A. PENDAHULUAN}

Penyebaran virus Covid-19 mulai akhir tahun 2019 lalu telah mengguncang dunia. Imbasnya, pandemi ini menghantam seluruh lapisan masyarakat, seluruh sektor; informal, formal, orang kaya maupun miskin. Wabah Covid-19 menyebabkan banyak negara di dunia mengalami resesi (Handayani, 2020). Physical distancing dan social distancing yang sedang berjalan untuk mencegah penyebaran Covid-19 mengakibatkan perekonomian masyarakat tersendat teerutama dibidang rumah tangga, UMKM, perusahaan dan finansial (Apriyanti, 2020). Masyarakat kota Depok menjadi salah satu yang ikut terdampak dari penyebaran Covid-19 ini. Bahkan, Depok menjadi kawasan dengan kasus Covid-19 paling tinggi se-Jawa Barat berdasarkan temuan per 15/9/2020 (Kontan.co.id, 2020).

Kebijakan Pembatasan Sosial Berskala Besar (PSBB) yang diterapkan sejak April lalu belum efektif menekan penyebaran Covid-19 di Depok. Ini disebabkan mobilitas menggunakan transportasi publik tetap tinggi khususnya warga yang bekerja di Jakarta. Di sisi lain, keputusan PSBB ini mengakibatkan kegiatan perekonomian di wilayah Depok ikut menjadi lumpuh karena adanya pemberlakuan jam operasional usaha. Keadaan ini menyebabkan ekonomi keluarga menjadi lebih buruk. Akibatnya, sebanyak 30.000 Kepala Keluarga di Depok terdampak secara ekonomi. Mereka adalah kelompok masyarakat yang kehilangan penghasilan seperti sopir ojek dan pedagang kecil. Dikhawatirkan kondisi ini membuat institusi keluarga sulit bertahan di tengah wabah Covid 19. Kenyataan ini sangat memprihatinkan mengingat lemahnya ketahanan ekonomi keluarga dalam bertahan menghadapi wabah berpeluang akan menimbulkan banyak persoalan baru antara lain, kemiskinan, masalah kesehatan mental, kekerasan dalam rumah tangga, kriminalitas, gizi buruk dan lain-lain (Okezone.com, 2020). Kebijakan \#DiRumahAja dalam menurunkan penyebaran Covid-19 untuk waktu yang panjang menyebabkan pekerja dengan upah harian pendapatannya turun. Hampir semua lini usaha akan terdampak dari kemungkinan penurunan ekonomi akibat Covid-19 (Irawaty, 2020, hal. 2). Penyaluran bantuan Jaring Pengaman Sosial sebesar Rp7,5 Milyar oleh pemerintah kota Depok (Okezone.com, 2020) belum efektif menjadi solusi dalam masalah ini.

Keluarga sebagai sistem sosial terkecil, juga sebagai lingkungan sosial pertama yang memperkenalkan cinta kasih, moral keagamaan, sosial budaya yang memainkan peranan dalam mencapai kesejahteraan penduduk yang menjadi citacita pembangunan (BPS \& PPPA, 2016, hal. 5). Oleh sebab itu, diperlukan kemampuan materil dari keluarga untuk mengatasi permasalahan ekonomi berdasarkan sumber daya yang dimiliki yang disebut ketahanan ekonomi (BPS \& PPPA, 2016, hal. 79). Aspek ekonomi dalam ketahanan ekonomi sangat berkaitan erat dengan pemenuhan kebutuhan konsumsi yang meliputi produksi, distribusi serta konsumsi barang dan jasa sehingga upaya meningkatkan taraf hidup masyarakat secara individu maupun kelompok tercapai (Marlinah, 2017). Ini dimulai dengan membangun ketahanan ekonomi keluarga. Penelitian ini bertujuan untuk mengetahui ketahanan ekonomi keluarga di Depok pada masa pandemi Covid-19. Melalui ketahanan ekonomi keluarga yang baik maka keluarga dapat bertahan menghadapi masa pandemi ini. 


\section{B. KAJIAN PUSTAKA}

\section{Definisi Ketahanan Ekonomi Keluarga}

Ketahanan ekonomi keluarga dipahami sebagai keadaan dinamis suatu keluarga mengenai kegigihan dan kekuatan dalam menghadapi berbagai tantangan, ancaman, dan hambatan serta gangguan baik dari eksternal maupun dari internal, secara langsung maupun tidak langsung membahayakan kelangsungan perekonomian keluarga. Sebagai unit terkecil dari sebuah negara, keluarga dengan ketahanan ekonomi yang kuat akan menciptakan dasar ekonomi negara yang kuat pula (Wulandari, 2017).

\section{Dimensi Ketahanan Ekonomi Keluarga}

BKKBN dan Kementerian PPPA (BPS \& PPPA, 2016, hal. 79-100) menjelaskan dimensi dalam mengukur ketahanan ekonomi, antara lain:

1) Tempat tinggal, diukur berdasarkan status kepemilikan rumah, yaitu: a) Milik sendiri, b) Mengontrak/sewa, c) Menumpang (bebas sewa), d) Rumah dinas.

2) Pendapatan keluarga, diukur dengan indikator: a) Pendapatan perkapita keluarga. Semakin tinggi pendapatan perkapita, maka ketahanan ekonomi keluarga menjadi lebih baik. b) Kecukupan pendapatan keluarga yang diukur berdasarkan persepsi subjektif kepala rumah tangga terkait kecukupan pendapatan rumah tangga untuk memenuhi kebutuhan sehari-hari. Persepsi subjektif ini menitikberatkan pada kepuasan rumah tangga atas pendapatan yang didapat. Asumsinya semakin tinggi penghasilan maka semakin puas rumah tangga tersebut akan kondisi ekonominya.

3) Pembiayaan pendidikan anak yang diukur melalui dua indikator, yaitu: a) Kemampuan pembiayaan pendidikan anak usia 7-18 tahun; b) Keberlangsungan pendidikan anak berdasarkan persentase keluarga yang memiliki anggota keluarga yang putus sekolah pada rentang usia 7-18 tahun akibat tidak menyelesaikan pendidikan maupun yang tidak sekolah.

4) Jaminan keuangan keluarga yang diukur melalui dua indikator, yaitu: a) Tabungan keluarga. b) Jaminan kesehatan keluarga berdasarkan kepemilikan asuransi kesehatan atau lainnya minimal satu anggota keluarga.

\section{Definisi Keluarga}

Kementerian Kesehatan (Kemenkes, 2016, hal. 19) menyebutkan bahwa keluarga adalah satuan terkecil dari masyarakat, terdiri atas ayah, ibu, dan anak (keluarga inti) maupun yang terdiri atas individu lain dengan ikatan darah bahkan juga tanpa ada ikatan darah (keluarga luas).

BPS dan Kementrian PPPA (BPS \& PPPA, 2016) menjelaskan empat karakteristik keluarga, yaitu: 1) Terdiri dari beberapa individu yang disatukan dalam ikatan seperti pernikahan, ikatan darah, atau adopsi 2) Anggota keluarga 
hidup dan menetap bersama-sama di suatu tempat; atau bangunan di bawah satu atap dalam susunan satu rumah tangga. 3) Setiap anggota keluarga saling berinteraksi, berkomunikasi, dan menciptakan peran sosial bagi setiap anggota, seperti: suami dan istri, ayah dan ibu, putera dan puteri, saudara laki-laki dan saudara perempuan, dan sebagainya. 4) Hubungan antar anggota keluarga merupakan representasi upaya pemeliharaan pola-pola kebudayaan bersama yang diperoleh dari kebudayaan umum di komunitas.

\section{METODE PENELITIAN}

Penelitian ini menggunakan metode kualitatif deskriptif. Subjek penelitian adalah keluarga di Depok sebanyak 100 orang. Metode pengumpulan data berupa wawancara tak berstruktur dan dokumentasi. Metode analisis data dilakukan dalam beberapa tahapan sebagai berikut (Herdiansyah, 2010, hal. 334):

1. Pengumpulan data berasal dari hasil wawancara, studi dokumen dan observasi

2. Klarifikasi materi data untuk memilih data yang dapat dijadikan acuan untuk penelitian selanjutnya. Mengklarifikasi materi dapat dilakukan dengan mengelompokkan data yang diperoleh dari hasil wawancara, studi dokumen dan observasi.

3. Penyajian data, data yang telah ada dideskripsikan secara verbal kemudian diberikan penjelasan dan uraian berdasarkan pemikiran yang logis, serta memberikan argumentasi dan dapat ditarik kesimpulan.

\section{HASIL DAN PEMBAHASAN}

Gambaran Profil Subjek Penelitian

Tabel 1.

Gambaran Profil Subjek Penelitian

\begin{tabular}{lcc}
\hline \multicolumn{3}{c}{ Peran Dalam Keluarga } \\
\hline Keterangan & Jumlah & Persentase \\
Suami/ayah & 14 orang & $14 \%$ \\
Istri/ibu & 34 orang & $34 \%$ \\
Anak & 52 orang & $52 \%$ \\
Jumlah & 100 orang & $100 \%$ \\
& & \\
Pekerjaan & & \\
Pegawai Negeri Sipil & 3 orang & $3 \%$ \\
Guru/Dosen & 17 orang & $17 \%$ \\
TNI/Polri & - & - \\
Pegawai Swasta & 32 orang & $32 \%$ \\
Ibu Rumah Tangga & 9 orang & $9 \%$ \\
Pedagang & - & - \\
Wiraswasta & 5 orang & $5 \%$ \\
Buruh Pabrik & - & - \\
Mahasiswa & 34 orang & $34 \%$ \\
\hline \multicolumn{1}{c}{ Jumlah } & 100 orang & $100 \%$ \\
\hline \multicolumn{2}{c}{ Sumber: Data diolah (2020) } \\
\multicolumn{2}{c}{}
\end{tabular}


Subjek dalam penelitian berjumlah 100 orang, yang terdiri dari suami/ayah 14 orang atau $14 \%$, istri/ibu 34 orang atau $34 \%$ dan anak sebanyak 52 orang atau $52 \%$. Tabel di atas menunjukkan bahwa sebanyak 3 persen responden adalah Pegawai Negeri Sipil (PNS), 17 persen adalah dosen, 32 persen merupakan karyawan swasta, 9 persen adalah Ibu Rumah Tangga (IRT), 5 persen merupakan wiraswasta, 34 persen memiliki pekerjaan mahasiswa.

\section{Hasil Penelitian}

Ketahanan ekonomi keluarga selama Masa Pandemi Covid-19 diukur berdasarkan indikator-indikator yang dijelaskan sebagai berikut:

\section{Tempat Tinggal Keluarga}

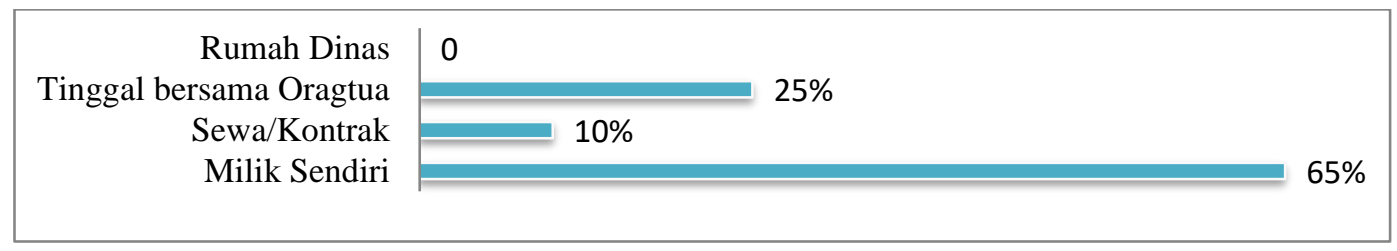

Sumber: Data diolah (2020)

Gambar 1.

Kepemilikan Tempat Tinggal

Gambar 1 menunjukkan bahwa sebagian besar keluarga yaitu sebanyak 65\% rumah tangga sudah memiliki rumah dengan status milik sendiri dan hanya $10 \%$ yang menyewa atau mengontrak. Ini mengindikasikan bahwa ketahanan ekonomi keluarga di Depok sudah baik. Selanjutnya ketahanan ekonomi keluarga menggunakan dimensi pendapatan perkapita akan dijelaskan melalui gambar 2 berikut ini.

\section{Pendapatan Perkapita Sebelum dan Selama Pandemi}

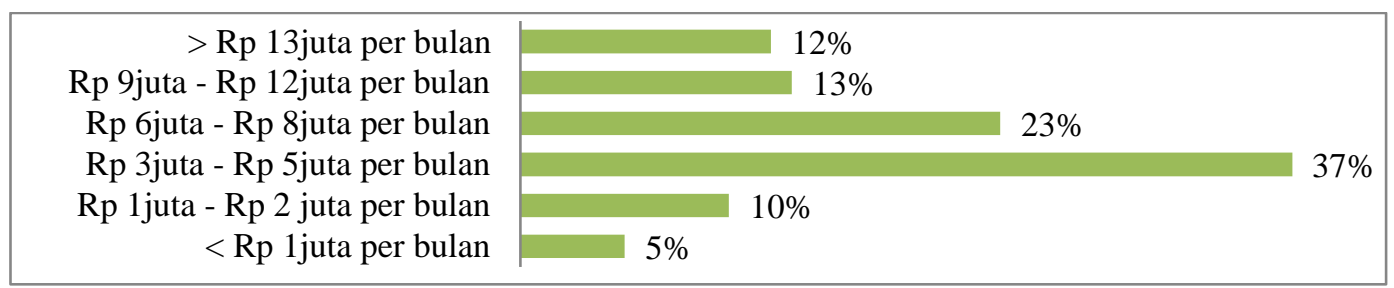

Sumber: Data diolah (2020)

Gambar 2.

Pendapatan perkapita Sebelum Pandemi

Gambar 2 menunjukkan bahwa pendapatan perkapita keluarga sebelum masa pandemi Covid-19 terdiri atas kurang dari Rp1.000.000 sebulan sebesar 5\%, kisaran Rp1.000.000 - Rp2.000.000 sebesar 10\%, kisaran Rp3.000.000 - Rp5.000.000 sebesar 37\%, Rp6.000.000 - Rp8.000.000 sebesar 23\%, kisaran Rp9.000.000 Rp12.000.000 sebesar 13\%, dan lebih dari Rp13.000.000 adalah sebesar 12\%. Garis 
kemiskinan yang berlaku di kota Depok adalah keluarga dengan pendapatan Rp644.860 sebulan.

Oleh sebab itu, ketahanan ekonomi keluarga di kota Depok sebelum masa pandemi adalah sudah baik karena sebanyak 95\% keluarga sudah berada di atas garis kemiskinan. Sementara itu, berdasarkan batasan Upah Minimum Kota (UMK) Depok tahun 2019 adalah sebesar Rp3.872.551 (Radardepok, 2019), maka sebanyak $85 \%$ keluarga sudah mendapatkan penghasilan sebulan sesuai dengan UMK Depok yang berlaku.

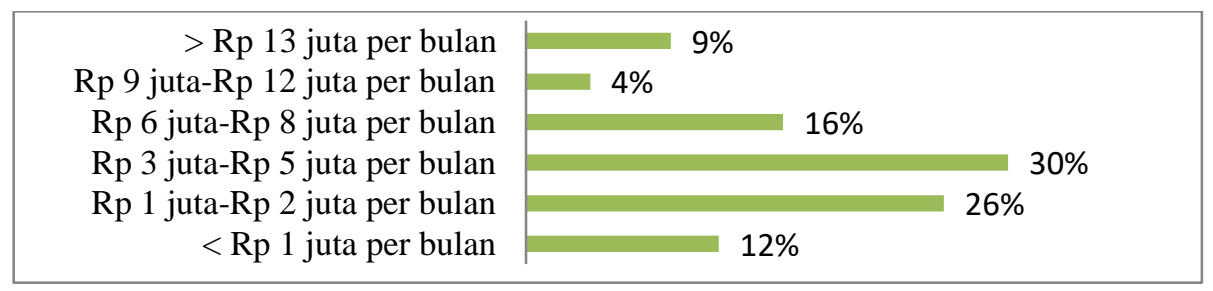

Sumber: Data diolah (2020)

Gambar 3.

Pendapatan Perkapita selama Masa Pandemi

Gambar 3 menunjukkan bahwa terdapat $12 \%$ yang mendapatkan penghasilan per kapita kurang dari Rp1.000.000 sebulan; dimana sebelum pandemi sebesar 5\%, sebesar 26\% mendapatkan penghasilan kisaran Rp1.000.000 - Rp2.000.000 sementara sebelum pandemi sebesar 10\%, sebesar 30\% mendapatkan penghasilan pada kisaran Rp3.000.000 - Rp5.000.000 sebulan sedangkan sebelum pandemi sebesar 37\%, sebesar 16\% berpenghasilan Rp6.000.000 - Rp8.000.000 dimana sebelum pandemi adalah sebesar 23\%, terdapat $4 \%$ berpenghasilan Rp9.000.000 Rp12.000.000 sebulan dimana sebelum pandemi adalah 13\% dan 9\% berpenghasilan lebih dari Rp13.000.000 dengan sebelumnya sebesar 12\%. Terdapat perubahan yang cukup signifikan khususnya pada golongan pendapatan kurang dari Rp1.000.000 sebulan. Tidak dapat dipungkiri terjadi penurunan pendapatan selama masa pandemi Covid-19.

\section{Kecukupan Pendapatan Keluarga Sebelum Dan Selama Pandemi Covid 19}

Kecukupan pendapatan keluarga diukur berdasarkan persepsi atau pandangan subjektif keluarga dalam menilai kemampuan memenuhi kebutuhan keluarga yang ditunjukkan dengan gambar berikut:

\begin{tabular}{|r|cc|}
\hline Lebih dari mencukupi kebutuhan keluarga & & $21 \%$ \\
Mampu memenuhi kebutuhan keluarga & & $74 \%$ \\
Tidak/kurang memenuhi kebutuhan keluarga & $4 \%$ & \\
Sangat tidak cukup memenuhi kebutuhan... & $1 \%$ & \\
\end{tabular}

Sumber: Data diolah (2020)

Gambar 4.

Kecukupan Pendapatan Keluarga Sebelum Masa Pandemi 
Gambar 4 memperlihatkan bahwa sebelum pandemi, terdapat 1\% yang beranggapan sangat tidak cukup memenuhi kebutuhan keluarganya, sebanyak $4 \%$ merasa tidak/kurang memenuhi kebutuhan keluarga, sebanyak $74 \%$ yang merasa mampu memenuhi kebutuhan keluarga, dan sebanyak $21 \%$ lebih dari mencukupi kebutuhan keluarga.

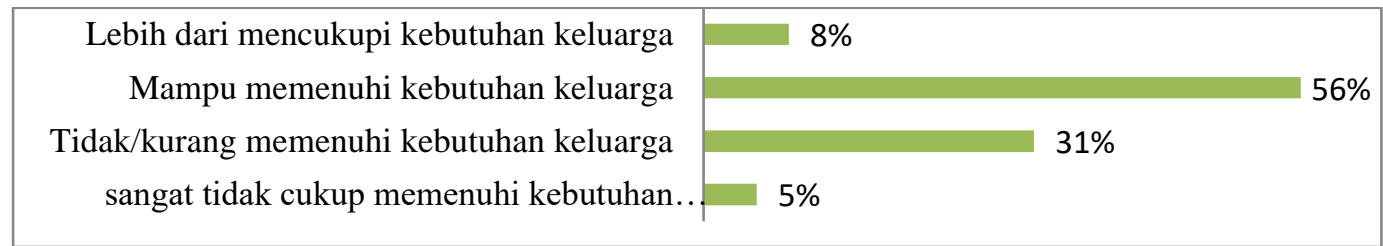

Sumber: Data diolah (2020)

\section{Gambar 5. \\ Kecukupan Pendapatan Keluarga Pada Masa Pandemi}

Gambar 5 memperlihatkan bahwa terdapat 5\% beranggapan sangat tidak cukup memenuhi kebutuhan keluarga; sementara sebelum pandemi sebesar $1 \%$, terdapat $31 \%$ merasa tidak/kurang memenuhi kebutuhan keluarga sedaangkan sebelum pandemi adalah $4 \%$. terdapat $56 \%$ mampu memenuhi kebutuhan keluarga sementara sebelum pandemi sebanyak $74 \%$. Keluarga yang beranggapan lebih dari mencukupi kebutuhan keluarga saat pandemi adalah sebanyak 8\% orang, dimana sebelum pandemi sebesar $21 \%$. Masa pandemi juga membuat keluarga merasa khawatir tidak dapat mencukupi kebutuhan keluarga, terlebih lagi jika terdapat kepala keluarga yang kehilangan pekerjaan.

\section{Pembiayaan Pendidikan Anak}

Kemampuan pembiayaan pendidikan anak usia 7-18 tahun

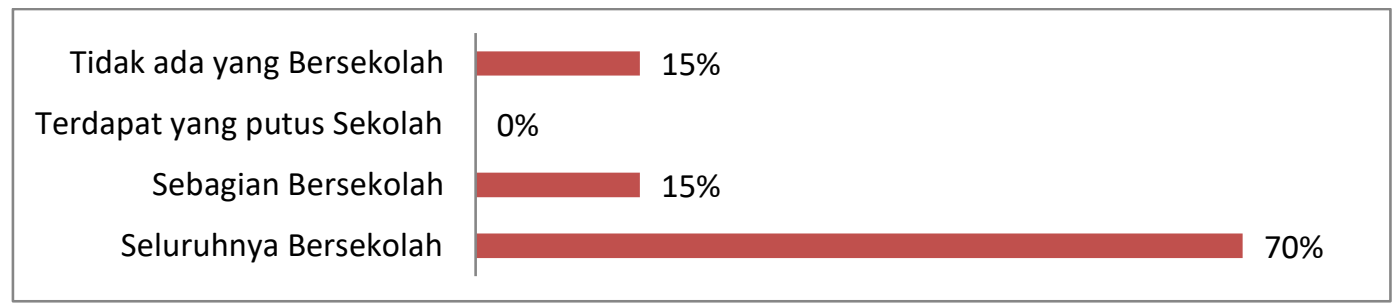

Sumber: Data diolah (2020)

\section{Gambar 6.}

\section{Kemampuan Pembiayaan Pendidikan Anak Usia 7-18 tahun}

Gambar 6 menunjukkan bahwa sebanyak 69\% memiliki anak berusia 7-18 tahun dengan status seluruhnya bersekolah yang berarti mampu membiayai pendidikan sampai dengan jenjang SMA, sedangkan $14 \%$ hanya sebagian yang bersekolah, dan sebanyak 15\% memiliki anak usia 7-18 tahun dengan status tidak ada yang bersekolah. 


\section{Keberlangsungan pendidikan anak}

Ada anggota keluarga yang putus sekolah

Tidak ada anggota keluarga yang putus sekolah

\section{$30 \%$}

Sumber: Data diolah (2020)

\section{Gambar 7.}

\section{Keberlangsungan Pendidikan Anak Usia 7-18 tahun}

Gambaran keberlangsungan pendidikan anak usia 7-18 tahun ditunjukkan dengan Gambar 7 dimana terdapat 70\% mampu menjamin pendidikan anak 7-18 tahun dan sebanyak 30\% rumah tangga memiliki anak usia 7-18 tahun yang putus sekolah. Hasil ini menunjukkan bahwa semakin tinggi keberlangsungan pendidikan anak usia 7-18 tahun maka semakin tinggi ketahanan ekonomi keluarga. Kemampuan orangtua dalam menjamin keberlangsungan pendidikan dapat dipengaruhi oleh latar pendidikan orangtuanya yang akan dijelaskan melalui Gambar 8 berikut ini.

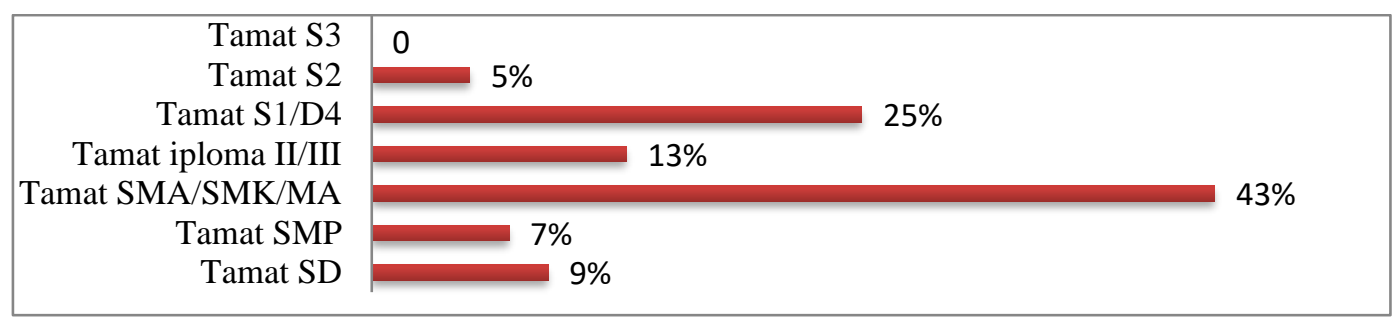

Sumber: Data diolah (2020)

Gambar 8.

Pendidikan Terakhir Ayah atau Suami

Gambar 8 menunjukkan bahwa sebanyak 7\% suami atau ayah memiliki latar pendidikan tamat SD, sebanyak 7\% tamat SMP, sebanyak $40 \%$ tamat SMA/SMK/MA, sebanyak 13\% tamat Diploma II/III, sebanyak 25\% lulusan S1/D4, sebanyak 5\% tamat S2. Latar pendidikan Ibu atau istri akan dijelaskan melalui Gambar 9 berikut ini:

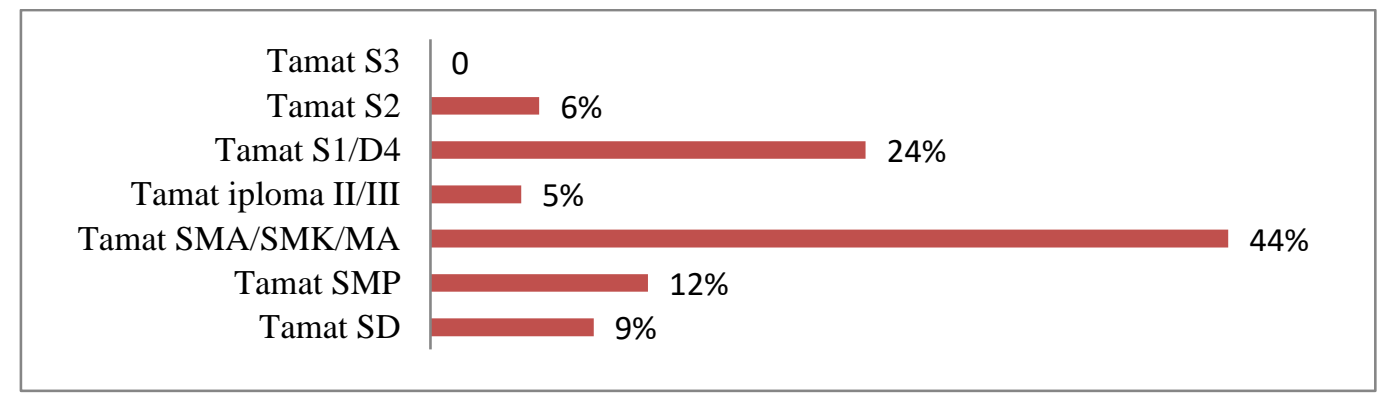

Sumber: Data diolah (2020)

Gambar 9.

Pendidikan Terakhir Istri atau Ibu 
Gambar 9 menunjukkan bahwa sebanyak 9 persen ibu atau istri berlatar pendidikan SD, sebanyak 12 persen tamat SMP, sebanyak 44 persen tamat SMA/SMK/MA, sebanyak 5 persen tamat Diploma II/III, sebanyak 24 orang tamat pendidikan S1/D4, sebanyak 6 persen tamat pendidikan S2.

Semakin tinggi latar belakang pendidikan orangtua, maka semakin tinggi keinginan untuk dapat membiayai pendidikan anak-anaknya hingga ke jenjang yang lebih tinggi. Orangtua akan berusaha semaksimal mungkin untuk menjamin pendidikan anak-anaknya jangan sampai ada yang putus sekolah atau bahkan tidak bersekolah.

\section{Jaminan Keuangan Keluarga}

\section{Ketersediaan tabungan keluarga}

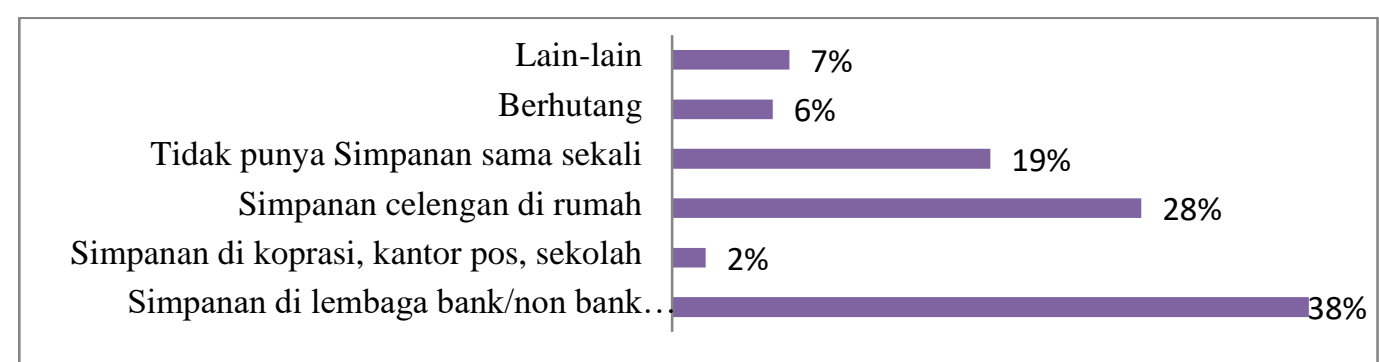

Sumber: Data diolah (2020)

Gambar 10.

Ketersediaan Tabungan Keluarga

Gambar 10 menunjukkan bahwa 38\% keluarga telah memiliki tabungan di lembaga bank/non bank, sebanyak $2 \%$ memiliki simpanan di koperasi, kantor pos dan sekolah, sebanyak 28\% memiliki simpanan celengan di rumah, $19 \%$ tidak memiliki simpanan sama sekali, sebanyak 6\% berhutang dan sebanyak $7 \%$ memiliki simpanan dalam bentuk lain. 68 persen keluarga di Depok memiliki ketahanan ekonomi yang cukup tinggi karena sudah memiliki simpanan atau tabungan.

\section{Ketersediaan jaminan kesehatan}

\begin{tabular}{|r|r|}
\hline Tidak memiliki BPJS/asuransi kesehatan... & 4\% \\
Asuransi kesehatan non BPJS sebagian... & $3 \%$ \\
Asuransi kesehatan non BPJS seluruh... & 11\% \\
BPJS Kesehatan sebagian anggota keluarga & $7 \%$ \\
BPJS Kesehatan seluruh anggota keluarga & \\
\hline
\end{tabular}

Sumber: Data diolah (2020)

Gambar 11.

Jaminan Kesehatan 
Gambar 11 menunjukkan bahwa terdapat 75\% keluarga telah memiliki BPJS Kesehatan bagi seluruh anggota keluarga, sebanyak 7\% memliki BPJS Kesehatan bagi sebagian anggota keluarga, 11\% memiliki Asuransi kesehatan non BPJS untuk seluruh anggota keluarga, 3\% memiliki Asuransi kesehatan non BPJS untuk sebagian anggota keluarga, dan 4\% keluarga tidak memiliki BPJS ataupun asuransi kesehatan non BPJS. Berdasarkaan hasil ini maka 96\% persen keluarga di Depok memiliki ketahanan ekonomi yang tinggi karena telah memiliki BPJS kesehatan ataupun asuransi kesehatan non BPJS.

\section{Pembahasan Hasil Penelitian}

Berdasarkan indikator kepemilikan tempat tinggal menunjukkan bahwa $65 \%$ rumah tangga telah memiliki tempat tinggal sendiri. Rumah tangga yang memilliki tempat tinggal sendiri memiliki ketahanan ekonomi yang lebih baik daripada rumah tangga yang masih menyewa atau mengontrak maupun yang masih tinggal bersama orangtua. Ini karena keluarga yang memiliki tempat tinggal sendiri telah memenuhi kebutuhan dasar atau primer mereka.

Pendapatan menjadi unsur penting dalam membangun ekonomi keluarga. Hasil penelitian menunjukkan bahwa terdapat $12 \%$ rumah tangga yang masih berpenghasilan kurang dari Rp1.000.000 per bulan selama masa pandemi. Pendapatan keluarga selama masa pandemi Covid-19 mengalami penurunan yang signifikan. Pakar Ekonomi Keluarga IPB Istiqlaliyah (Kompas.com, 2020) menyatakan bahwa sebanyak $55.5 \%$ keluarga di Indonesia mengalami penurunan pendapatan yang menyebabkan $63 \%$ masyarakat mengalami kekhawatiran akan memburuknya perekonomian keluarga. Ini didukung dengan hasil survei oleh LSI di delapan propinsi zona merah, yaitu DKI Jakarta, Jawa Barat, Sumatera Utara, Jawa Tengah, Jawa Timur, Sulawesi Selatan, dan Bali yang menunjukkan bahwa sebanyak $74,8 \%$ responden menyatakan keadaan ekonomi mereka lebih buruk. Bahkan, persepsi kondisi ekonomi buruk selama pandemi dialami hampir semua kalangan, baik dari segi usia, agama, maupun pendapatan per bulan. Selain itu, keluarga yang berpenghasilan di bawah Rp1.500.000 merupakan yang paling khawatir tidak mampu memenuhi kebutuhan hidup sehari-hari pada masa pandemi (Mediaindonesia.com, 2020). Namun, hasil berbeda didapat dari penelitian ini dimana terdapat $31 \%$ keluarga di Depok merasa tidak/kurang dapat memenuhi kebutuhan keluarga selama masa pandemi sedangkan $56 \%$ merasa mampu memenuhi kebutuhan. Ini menunjukkan keluarga di Depok sebagian besar merasa optimis dapat memenuhi kebutuhan hidup dimasa pandemi meskipun mengalami penurunan penghasilan.

Meski demikian, pandemi Covid-19 ini pada hakikatnya telah menurunkan kemampuan penghasilan keluarga di Depok dalam memenuhi kebutuhan, walau tidak signifikan penurunannya, yaitu sebesar $18 \%$. Dimana sebelum pandemi terjadi $74 \%$ keluarga mampu memenuhi kebutuhannya dan munculnya pandemi, hanya 56\% keluarga masih optimis mampu mencukupi kebutuhan keluarga.

Untuk itu, perlu strategi agar keluarga bisa bertahan menghadapi pandemi. Pakar Ekonomi Keluarga IPB Istiqlaliyah (Kompas.com, 2020) menggagas diperlukannya coping strategy dimana keluarga harus berupaya untuk memecahkan masalah dengan mengubah perilaku, lingkungan serta pengendalian emosi. 
Beberapa hal yang dapat dilakukan dengan mengurangi jajan, mengurangi jenis lauk, bahkan bisa dengan mengurangi frekuensi makan. Selain itu menjaga ketahanan ekonomi selama masa pandemi dapat dilakukan dengan menambah sumber pendapatan keluarga agar pendapatan keluarga meningkat, salah satunya memulai bisnis keluarga dengan memiliki aset digital. Usaha yang dapat dilakukan untuk menambah pendapatan antara lain (Irawaty, 2020): 1) Usaha kuliner berupa lauk pauk dengan sistem siap diantar; 2) Usaha rempah tradisional, jamu, atau herbal yang fresh dan siap antar; 3) Bahan baku makanan dengan sistem siap antar; 4) Usaha garmen pembuatan master kain yang unik atau Alat Pelindung Diri (APD); dan 5)Usaha pulsa, listrik, telepon dan internet.

Dalam hal dimensi pembiayaan pendidikan, hasil penelitian menunjukkan bahwa ketahanan ekonomi keluarga di Depok sudah baik untuk seluruh indikator. Namun, pelaksanaan pembelajaran daring imbas kebijakan PSBB menimbulkan masalah. Kebijakan social distancing selama pandemi juga berdampak terhadap bidang pendidikan anak usia 7-18 tahun. Keputusan pemerintah meliburkan dan mengubah metode pembelajaran dari tatap muka menjadi pembelajaran daring dari rumah bukan hal yang mudah dilakukan. Terdapat beberapa faktor yang menghambat pelaksanaan pembelajaran daring, antara lain (Nuryana, 2020): penguasaan teknologi yang masih rendah, keterbatasan sarana dan prasarana, jaringan internet; dan biaya. Jika terus dibiarkan, maka besar kemungkinan anak usia 7-18 tahun menjadi putus sekolah akan terjadi. Kebijakan pemerintah melalui pemberian subsidi kuota internet gratis untuk mendukung penyelenggaraan pendidikan jarak jauh (Republika.co.id, 2020) juga harus didukung oleh perbaikan yang lain agar subsidi ini menjadi tepat sasaran dan dapat dinikmati tidak saja guru dan siswa di perkotaan namun juga dapat dinikmati sampai ke pelosok. Ini dilakukan agar tidak ada anak usia 7-18 tahun menjadi putus sekolah pada masa pandemi.

Berdasarkan indikator jaminan keuangan keluarga, hasil penelitian menunjukkan bahwa keluarga di Depok sudah memiliki ketahanan ekonomi yang baik karena sebagian besar telah memiliki tabungan keluarga dan asuransi kesehatan, baik BPJS maupun non BPJS. Tabungan merupakan bagian dari dana darurat yang harus dipersiapkan untuk membiayai kebutuhan yang terjadi di luar rencana. Terdapat berbagai manfaat memiliki asuransi kesehatan, antara lain (Detikhealth, 2020): 1) Membuat pikiran tenang. karena memberikan kesempatan dalam penjagaan kesehatan; 2) Meningkatkan kesehatan karena adanya jaminan dari perusahaan asuransi bahwa setiap masalah kesehatan dapat diselesaikan sehingga kesehatan akan terjamin; 3) Meningkatkan penghematan karena tidak perlu menghabiskan tabungan sehingga kebutuhan sosial lainnya dapat terpenuhi; 4) Pemeriksaan kesehatan dapat dilaksanakan secara konsisten; 5) Melindungi keuangan karena biaya kesehatan sudah ditanggung asuransi.

Masa pandemi menuntut keluarga berpikir ulang dalam mengelola keuangan keluarga sehingga ketahanan ekonomi tetap dapat terjaga menurut Prita H. Ghozie (ojk.go.id, 2020) dan (Irawaty, 2020), antara lain : 1) Mengevaluasi sumber pendapatan dengan cara membagi anggaran rumah tangga menjadi tiga pos, yaitu living, saving dan playing 2) Mengatur ulang budget rumah tangga dengan cara memprioritaskan kebutuhan utama; 3) Menyiapkan dana darurat; 4) 
Mempertimbangkan untuk menjual barang-barang yang bersifat tersier dan jarang digunakan serta pertimbangkan opsi gadai untuk keperluan dana darurat; 5) Mencari kegiatan yang bersifat minim modal, misalnya mengikuti kelas online pada media IG, atau Whatsapp secara gratis; dan 6) Menunda pembelian secara cicilan.

\section{E. SIMPULAN DAN SARAN}

\section{Simpulan}

Berdasarkan indikator kepemilikan tempat tinggal, pendapatan keluarga, pembiayaan pendidikan anak, dan jaminan keuangan keluarga didapati bahwa ketahanan ekonomi keluarga di Depok dimasa pandemi Covid-19 mengalami penurunan dari sisi pendapatan dan kemampuan memenuhi kebutuhan keluarga. Dimana sebelum pandemi sebanyak $74 \%$ keluarga mampu memenuhi kebutuhan, tapi saat pandemi berkurang $18 \%$ menjadi $56 \%$. Namun dari aspek kepemilikan tempat tinggal, pembiayaan pendidikan anak, dan jaminan keuangan keluarga, ketahanan ekonomi keluarga di Depok dapat dinilai cukup baik. Rekomendasi dari penelitian ini adalah diperlukan strategi untuk mempertahankan ketahanan ekonomi keluarga berupa pengelolaan keuangan keluarga, dan perlu dilakukan penelitian pengukuran ketahanan finansial keluarga dalam menghadapi goncangan ekonomi seperti adanya wabah Covid-19 ini. 


\section{DAFTAR PUSTAKA}

Apriyanti, H. W. (2020). Potret Ketahanan Ekonomi dan Pangan Keluarga di Era Pandemi Covid-19. Dipetik 07 20, 2020, dari www.suarabaru.id: http://suarabaru.id/2020/05/06/potret-ketahanan-ekonomi-dan-ketahananpangan-keluarga-di-era-pandemi-Covid-19/

BPS, \& PPPA, K. (2016). Pembangunan Ketahanan Keluarga 2016. Jakarta: Kementrian Pemberdayaan Perempuan dan Perlindungan Anak.

Detikhealth. (2020). 5 Manfaat Miliki Asuransi Kesehatan Keluarga Saat Pandemi Covid-19. Dipetik 08 30, 2020, dari www.detik.com: https://m.detik.com/health/berita-detikhealth/d-4980815/5-manfaat-milikiasuransi-kesehatan-keluarga-saat-pandemi-covid-19

Handayani, L. (2020). https://www.suaramerdeka.com/news/opini/228739-perankeluarga-hadapi-pandemi-covid-19. Dipetik 07 18, 2020, dari www.suaramerdeka.com.

Herdiansyah, H. (2010). Metode Penelitian Kualitatif. Jakarta: Salemba Humanika.

Irawaty, D. K. (2020). Pengelolaan Keuangan Keluarga pada Era Pandemik Covid-19. Jakarta: Badan Kependudukan Keluarga Berencana Nasional.

Kemenkes. (2016). Buku Pedoman Umum Program Indonesia Sehat dengan Pendekatan Keluarga. Jakarta: Kementrian Kesehatan RI.

Kompas.com. (2020). Pakar IPB: 55,5 persen Keluarga di Indonesia Turun Penghasilan Selama Pandemi. Dipetik 08 23, 2020, dari www.kompas.com: https://edukasi.com.com/read/2020/06/20/192719171/pakar-ipb-555-persenkeluarga-di-indonesia-turun-penghasilan-selama-pandemi?page $=$ all

Kontan.co.id. (2020). Mengkhawatirkan, kasus Covid-19 di Depok melonjak 4 kali lipat dalam 2 bulan. Dipetik Januari 14, 2020, dari https://regional.kontan.co.id/news/mengkhawatirkan-kasus-covid-19-didepok-melonjak-4-kali-lipat-dalam-2-bulan

Marlinah, L. (2017). Meningkatkan Ketahanan Ekonomi Nasional Melalui Pengembangan Ekonomi Kreatif. Cakrawala, 258-265.

Mediaindonesia.com. (2020). Ekonomi Warga Anjlok Selama Pandemi. Dipetik 08 28, 2020, dari www.mediaindonesia.com: https://mediaindonesia.com/read/detail/326344-ekonomi-warga-anjlokselama-pandemi

Nuryana, A. N. (2020). Dampak Pandemi Covid-19 Terhadap Dunia Pendidikan. Dipetik 08 11, 2020, dari www.kabarpriangan.com: https://kabarpriangan.com/dampak-pandemi-covid-19-terhadap-dunia-pendidikan

Ojk.go.id. (2020). Strategi Atur Keuangan Saat Menghadapi Pandemi Covid-19. Dipetik $08 \quad 23, \quad 2020, \quad$ dari www.ojk.go.id: https://sikapiuangmu.ojk.go.id/FrontEnd/CMS/Article/20576 
Okezone.com. (2020). Terdampak Covid-19, 30 Ribu Warga Depok Dapat Bantuan Hingga Rp500.000. Diambil kembali dari www.megapolian.okezone.com: www.megapolian.okezone.com

Radardepok. (2019). https://www.radardepok.com/2019/12/angka-kemiskinandepok-terendah-di-jabar/. Dipetik 07 18, 2020, dari www.radardepok.com.

Republika.co.id. (2020). Kuota Internet Gratis untuk Siswa dan Guru Ini Perinciannya. Dipetik 08 28, 2020, dari www.republika.co.id: https://m.republika.co.id/berita/qfpmtj409/kuota-internet-gratis-untuksiswa-dan-guru-ini-perinciannya

Wulandari, P. K. (2017). Inovasi Pemuda dalam Mendukung Ketahanan Ekonomi Keluarga (Studi di Kampung Warna-Warni Kelurahan Jodipan, Kecamatan Blimbing, Kota Malang). Jurnal Ketahanan Nasional, Vol.23(No.3 Edisi Desember), 300-319. 